\title{
Studies on variability, heritability and genetic advance for yield and yield contributing characters in french bean (Phaseolus vulgaris L.) germplasm under tarai region of Uttarakhand
}

\author{
Ankit Panchbhaiya, Dhirendra Kumar Singh, Vinod Jatav, Sanganamoni Mallesh and \\ Priyanka Verma
}

Department of Vegetable Science, College of Agriculture, G.B. Pant University of Agriculture and Technology, Pantnagar- 263145 (Uttarakhand), India.

*Corresponding author E-mail: anki38423@gmail.com

Received: November 22, 2016; Revised received: April 15, 2017; Accepted: September 10, 2017

\begin{abstract}
Seventy four French bean germplasms were evaluated for twenty two quantitative traits to study the genetic variability, heritability and genetic advance during Jan-Feb in G.B. Pant University of Agriculture and Technology, Pantnagar. Significant differences were observed among all genotypes. Higher genotypic and phenotypic coefficient of variability were observed for plant height, seed yield per plant, pod yield per plant, pod yield per hectare, number of pods per cluster, number of pods per plant and 100 seed weight $(42.45 \%$ and $43.30 \%, 39.72 \%$ and $42.34 \%, 27.59 \%$ and $32.12 \%, 27.59 \%$ and $32.12 \%, 25.01 \%$ and $28.14 \%, 24.56 \%$ and $26.76 \%$ and $22.65 \%$ and $22.96 \%$ respectively). High heritability coupled with high genetic advance over mean were observed for plant height, seed yield per plant, pod yield per plant, pod yield per hectare, number of pods per plant, 100 seed weight, number of pods per cluster, leaf length, single pod weight, pod diameter, pod length, number of pod clusters per plant, leaf width, seed length, number of seeds per pod and seed width $(96.34 \%$ and $85.73 \%, 88.03 \%$ and $76.77 \%, 73.80 \%$ and $48.83 \%, 73.80 \%$ and $48.83 \%, 84.20 \%$ and $46.42 \%, 97.34 \%$ and $46.04 \%, 45.78 \%$ and $78.96 \%, 38.88 \%$ and $89.58 \%, 38.21 \%$ and $92.70 \%, 92.69 \%$ and $35.45 \%, 90.13 \%$ and $34.48 \%, 32.47 \%$ and $79.39 \%, 28.03 \%$ and $79.60 \%$, $26.92 \%$ and $99.04 \%, 56.27 \%$ and $24.85 \%$, and $97.82 \%$ and $24.01 \%$ respectively) indicate predominance additive gene action. Thus, there is ample scope for improving these characters through direct selection.
\end{abstract}

Keywords: French bean, GCV, Genetic variability, Heritability, PCV

\section{INTRODUCTION}

French bean (Phaseolus vulgaris L.), $2 \mathrm{n}=22$ is the most popular leguminous vegetable crop in many parts of the world. It belongs to the family Leguminoceae (Fabaceae), sub-family papilionaceae, order Leguminosales (Fabales), subtribe Phaseolinae, tribe Phaseolae. It is also known by many names as kidney bean, common bean, field bean, garden bean, faras bean, bush bean, navy bean, haricot bean, pinto bean, string bean, marrow bean, snap bean and dry beans etc. The large dry seed type varieties are called as 'Rajmash' in India. It is very popular among the people due to its quality, nutritional balance and higher biological efficiency. This vegetable plays a vital role in the nourishment of human population (Ram, 2014). India has about 137.54 thousand ha area under bean cultivation and the production is 1370.21 thousand MT with an annual productivity $9.96 \mathrm{MT} / \mathrm{ha}$ green pod (Anonymous, 2015). There are three types of french bean: Bush type with short internodes, semi-pole-type with longer internodes than those in bush type and the pole-type having longer internodes than that of the semi-pole type. Over 50 species of Phaseolus have been reported from the America, of these, only five, namely Common bean ( $P$. vulgaris L.), year bean $(P$. polyanthus $)$, scarlet or runner bean $(P$. coccineus $)$, tepary bean (P. acutifolius) and lima bean ( $P$. lunatus) are known to be domesticated. All the species are selfpollinated, except $P$. coccineus which is generally cross pollinated. French bean is domesticated in Mexico, Peru and Colombia. It is originated in new world, principally South Mexico and Central America (Vavilov, 1950). Radio carbon dates suggested that french bean was domesticated in Central America about 7000 years ago (Kaplan, 1965). In North America, the french bean spread through California. It was introduced into Europe in the $16^{\text {th }}$ and $17^{\text {th }}$ centuries and in England almost at the end of the $16^{\text {th }}$ century (1594). It was brought to India from Europe during the $17^{\text {th }}$ century (Swarup, 2012).

Success of a breeding programme is largely dependent on the extent of genetic variability present in the population of evolving promising and desired types. A detailed extent study of variability and heritability in relation to their contribution towards yield is prime requisite for an efficient plant breeding programme. 
The possibility of improvement in any crop is measured by variability available in the crop (Mohapatra et $a l ., 2007)$. The genetic variability in conjunction with total variability can be used in predicting the gain for a given selection intensity. The variation in the characters of any crop species is the raw material for a plant breeder and extent of variability present in the population with respect to various characters is the factor for the success of plant breeder in improvement of crop plant. Larger variability ensures better chances of producing desired crop variety. Hence, it is very essential to screen out the available germplasm for higher production of french bean.

\section{MATERIALS AND METHODS}

The present investigation was conducted at Vegetable Research Centre, G.B. Pant University of Agriculture and Technology, Pantnagar, U.S. Nagar (Uttarakhand) during Jan-May, 2014 which is located in tarai region of Uttarakhand. The experimental material comprised of seventy four genotypes of french bean (Table 1). The experiment was laid out in randomized block design with three replications. Each genotype was sown in three meter row length following plant spacing at 30 x $20 \mathrm{~cm}$ apart.

Observations were recorded on five randomly selected competitive plants per replication for each entry on twenty two quantitative traits namely, days to $1^{\text {st }}$ flowering, days to $50 \%$ flowering, days to $50 \%$ pod setting, days to $50 \%$ maturity, days to $1^{\text {st }}$ picking, days to $2^{\text {nd }}$ picking, , number of pods per cluster, number of pod clusters per plant, number of pods per plant, pod diameter, pod length, leaf length, leaf width, single pod weight, plant height, number of seeds per pod, seed length, seed width, 100 seed weight, seed yield per plant, pod yield per plant and pod yield per hectare. The analysis of variance for each character was followed according to Panse and Sukhatme (1967). The genotypic coefficient of variation (GCV) and phenotypic coefficient of variation (PCV) were calculated as per Burton and De Vane (1953). Heritability (broad sense) and genetic advance as per cent of mean were computed by following the methods of Johnson et al. (1955) and Allard (1960), respectively.

\section{RESULTS AND DISCUSSION}

The analysis of variance for all 22 quantitative characters of french bean showed significant difference (Table 2). The mean estimates of genotypes (Table 3) for various characters revealed that the wide range was recorded in seed yield per plant, plant height (Bhaganna et al., 2015, Prakash et al., 2015, Kamaluddin and Ahmed, 2011, Mukesh and Geeta, 2016 and Prakash and Ram, 2014), 100 seed weight (Bhaganna et al., 2015, Prakash et al., 2015, Kamaluddin and Ahmed, 2011, Mukesh and Geeta, 2016, Prakash and Ram, 2014 and Rai et al., 2010), number of pods per plant (Bhaganna et al., 2015, Prakash et al., 2015, Mukesh and Geeta, 2016, Prakash and Ram, 2014 and Rai et al., 2010), number of seeds per pod (Bhaganna et al., 2015, Mukesh and Geeta, 2016 and Prakash and Ram, 2014), pod length (Bhaganna et al., 2015, Mukesh and Geeta, 2016 and Rai et al., 2010), seed length, pod yield per plant (Bhaganna et al., 2015, Prakash et al., 2015, Mukesh and Geeta, 2016 and Prakash and Ram, 2014) and pod yield per hectare (Prakash et al., 2015 and Prakash and Ram, 2014). Traits like seed length and seed yield per plant revealed wide range in study conducted by Rai et al. (2010). While moderate range was recorded in days to $1^{\text {st }}$ flowering (Bhaganna et al., 2015, Prakash and Ram, 2014 and Rai et al., 2010), days to $50 \%$ flowering (Bhaganna et al., 2015, Prakash et al., 2015 and Prakash and Ram, 2014), days to 50\% pod setting, days to $1^{\text {st }}$ picking, days to $2^{\text {nd }}$ picking, days to $50 \%$ maturity, number of pods per cluster, number of pod clusters per plant, pod diameter, seed width, leaf length, leaf width and single pod weight. Prakash et al. (2015) and Prakash and Ram (2014) were also reported moderate range for leaf length, leaf width and single pod weight in french bean. For seed width and days to $1^{\text {st }}$ picking moderate range were reported by Rai et al. (2010).

Variation at phenotypic level is a combination of genetic as well as environmental variability, which does not help in effective selection. Hence, the decisive factors primarily rest on genotypic variability or more specifically, additive genetic variability in which a breeder is mostly interested. Statistics like range, mean and coefficient of variation provide basic information on the variation of a character at phenotypic and genotypic level. This also gives an indication of the influence of environment in bringing the variation. In the present investigation, phenotypic coefficient of variation was higher than that of genotypic coefficient of variation for all the characters under studied (Table 3). It may be because of the reason that the variability at phenotypic level includes both genotypic and environmental variability. For most of the characters, the differences in estimates of PCV and GCV were less, indicating that these characters were less affected by environment and therefore they were stable.

Highest genotypic as well as phenotypic coefficient of variations (Table 3) were exhibited by plant height (Kamaluddin and Ahmed, 2011, Prakash and Ram , 2014 and Prakash et al., 2015 ), followed by seed yield per plant (Kamaluddin and Ahmed, 2011), pod yield per plant (Prakash and Ram, 2014, Prakash et al., 2015 and Pandey et al., 2013), pod yield per hectare (Prakash and Ram, 2014 and Prakash et al., 2015), number of pods per cluster, number of pods per plant (Prakash and Ram, 2014, Prakash et al., 2015 and Pandey et al., 2013) and 100 seed weight (Prakash and Ram, 2014 and Prakash et al., 2015), while lowest in days to $2^{\text {nd }}$ picking, followed by days to $1^{\text {st }}$ picking, 
Table 1. List of germplasm of French bean (Phaseolus vulgaris L.).

\begin{tabular}{|c|c|c|c|c|c|c|c|}
\hline S. N. & Genotype & S.N. & Genotype & S.N. & Genotype & S.N. & Genotype \\
\hline 1. & Pant Anupama & 20 & FB-206 & 39. & FB-225 & 58. & FB-244 \\
\hline 2. & Pant Bean-2 & 21. & FB-207 & 40. & FB-226 & 59. & FB-245 \\
\hline 3. & Pant Bean-3 & 22. & FB-208 & 41. & FB-227 & 60. & FB-246 \\
\hline 4. & Arka Anoop & 23. & FB-209 & 42. & FB-228 & 61. & FB-247 \\
\hline 5. & Arka Komal & 24. & FB-210 & 43. & FB-229 & 62. & FB-248 \\
\hline 6. & Arka Suvidha & 25. & FB-211 & 44. & FB-230 & 63. & FB-249 \\
\hline 7. & Contender & 26. & FB-212 & 45. & FB-231 & 64. & FB-250 \\
\hline 8. & Chitra & 27. & FB-213 & 46. & FB-232 & 65. & FB-251 \\
\hline 9. & VL Bean-2 & 28. & FB-214 & 47. & FB-233 & 66. & FB-252 \\
\hline 10. & IIHR-909 & 29. & FB-215 & 48. & FB-234 & 67. & FB-253 \\
\hline 11. & VLFB-130 & 30. & FB-216 & 49. & FB-235 & 68. & FB-254 \\
\hline 12. & VLFB-510 & 31. & FB-217 & 50. & FB-236 & 69. & FB-255 \\
\hline 13. & VLFB-628 & 32. & FB-218 & 51. & FB-237 & 70. & FB-256 \\
\hline 14. & VLFB-629 & 33. & FB-219 & 52. & FB-238 & 71. & FB-257 \\
\hline 15. & FB-201 & 34. & FB-220 & 53. & FB-239 & 72. & FB-258 \\
\hline 16. & FB-202 & 35. & FB-221 & 54. & FB-240 & 73. & FB-259 \\
\hline 17. & FB-203 & 36. & FB-222 & 55. & FB-241 & 74. & FB-260 \\
\hline 18. & FB-204 & 37. & FB-223 & 56. & FB-242 & & \\
\hline 19. & FB-205 & 38. & FB-224 & 57. & FB-243 & & \\
\hline
\end{tabular}

Table 2. Analysis of variance for twenty two quantitative characters in french bean.

\begin{tabular}{lllll}
\hline S. N. & Characters & \multicolumn{3}{c}{ Mean sum of squares } \\
\cline { 3 - 5 } & & df & Genotype & Error \\
\cline { 3 - 4 } & & 1.27 & $\mathbf{7 3}$ & $\mathbf{1 4 6}$ \\
\hline 1 & Days to $1^{\text {st }}$ flowering & 0.22 & $31.58^{* *}$ & 1.93 \\
2 & Days to 50\% flowering & 1.23 & $37.81^{* *}$ & 1.64 \\
3 & Days to 50\% pod setting & 0.29 & $40.21^{* *}$ & 2.36 \\
4 & Days to 50\% maturity & 1.15 & $42.41^{* *}$ & 0.54 \\
5 & Days to $1^{\text {st }}$ picking & 0.66 & $34.71^{* *}$ & 0.51 \\
6 & Days to 2 ${ }^{\text {nd }}$ picking & 0.01 & $29.67^{* *}$ & 0.53 \\
7 & Number of pods/ cluster & 0.07 & $0.88^{* *}$ & 0.07 \\
8 & Number of pod clusters/ plant & 1.35 & $1.67^{* *}$ & 0.13 \\
9 & Number of pods/ plant & 0.05 & $12.89^{* *}$ & 0.76 \\
10 & Pod dia. (mm) & 0.86 & $10.46^{* *}$ & 0.27 \\
11 & Pod length (cm) & 0.43 & $11.33^{* *}$ & 0.40 \\
12 & Leaf length (cm) & 0.91 & $10.21^{* *}$ & 0.38 \\
13 & Leaf width (cm) & 0.00 & $3.44^{* *}$ & 0.27 \\
14 & Single pod weight (g) & 6.83 & $2.69^{* *}$ & 0.07 \\
15 & Plant height (cm) & 0.50 & $1016.23^{* *}$ & 13.56 \\
16 & Number of seeds/ pod & 0.07 & $1.20^{* *}$ & 0.41 \\
17 & Seed length (mm) & 0.05 & $9.92^{* *}$ & 0.03 \\
18 & Seed width (mm) & 0.55 & $1.93^{* *}$ & 0.01 \\
19 & 100 seed weight (g) & 0.46 & $169.58^{* *}$ & 1.53 \\
20 & Seed yield/plant (g) & 12.01 & $74.72^{* *}$ & 3.24 \\
21 & Pod yield/ plant (g) & $370.28^{* *}$ & 39.18 \\
22 & Pod yield/ ha (q) & 48.03 & $1481.14^{* *}$ & 156.72 \\
\hline
\end{tabular}

df : degree of freedom, $* *$ : Significant at $1 \%$ level

days to $50 \%$ maturity, days to $50 \%$ pod setting and days to 50\% flowering (Prakash and Ram, 2014 and Prakash et al., 2015) in french bean.

The study of genotypic coefficient of variation helps to measure the range of genotypic variation existing at specified environmental site for a particular character and to compare the variability existing in various characters. However, it cannot measure the heritable variation; the genotypic coefficient of variation together with heritability estimates would give reliable indication of the expected improvement through selection as reported by Burton and Devane (1953). Days to $1^{\text {st }}$ flowering, days to $50 \%$ flowering, days to $50 \%$ pod setting, days to $1^{\text {st }}$ picking, days to $2^{\text {nd }}$ picking and days to $50 \%$ maturity had low GCV, which indicates the existence of narrow genetic variability. It could be therefore, suggested that for the improvement of these characters, there is a need to create variability.

High heritability coupled with high genetic advance as per cent of mean (Table 3) was recorded in plant height, seed yield per plant, pod yield per plant, pod yield per hectare, number of pods per plant, 100 seed 
Table 3. Range, coefficient of variation, heritability, genetic advance, genetic advance as per cent of mean and genetic parameters for different quantitative characters of french bean.

\begin{tabular}{|c|c|c|c|c|c|c|c|c|}
\hline \multirow[b]{2}{*}{$\begin{array}{l}\text { S. } \\
\text { N. }\end{array}$} & \multirow[b]{2}{*}{ Characters } & \multirow[b]{2}{*}{ Range } & \multirow[b]{2}{*}{ GM } & \multirow[b]{2}{*}{ Sem } & \multicolumn{2}{|c|}{ Variability } & \multirow{2}{*}{$\begin{array}{l}\text { Herita- } \\
\text { bility } \\
\left(h^{2} \%\right) \\
\end{array}$} & \multirow{2}{*}{$\begin{array}{l}\text { Genetic ad- } \\
\text { vance as per } \\
\text { cent of mean }\end{array}$} \\
\hline & & & & & $\begin{array}{l}\text { GCV } \\
(\%) \\
\end{array}$ & PCV (\%) & & \\
\hline 1 & Days to $1^{\text {st }}$ flowering & $40.33-57.67$ & 44.71 & 0.8016 & 7.03 & 7.69 & 83.68 & 13.25 \\
\hline 2 & Days to $50 \%$ flowering & $44.00-60.00$ & 48.18 & 0.7385 & 7.21 & 7.68 & 88.05 & 13.93 \\
\hline 3 & $\begin{array}{l}\text { Days to } 50 \% \text { pod set- } \\
\text { ting }\end{array}$ & $47.00-63.67$ & 52.09 & 0.8873 & 6.82 & 7.43 & 84.23 & 12.89 \\
\hline 4 & Days to $50 \%$ maturity & $59.00-74.33$ & 63.98 & 0.4258 & 5.84 & 5.95 & 96.25 & 11.80 \\
\hline 5 & Days to $1^{\text {st }}$ picking & $57.00-71.33$ & 61.86 & 0.412 & 5.46 & 5.58 & 95.72 & 11.00 \\
\hline 6 & Days to $2^{\text {nd }}$ picking & $61.00-76.00$ & 66.65 & 0.4202 & 4.68 & 4.80 & 94.83 & 9.38 \\
\hline 7 & $\begin{array}{l}\text { Number of pods/ clus- } \\
\text { ter }\end{array}$ & $01.13-03.50$ & 2.08 & 0.1549 & 25.01 & 28.14 & 78.96 & 45.78 \\
\hline 8 & $\begin{array}{l}\text { Number of pod clus- } \\
\text { ters/ plant }\end{array}$ & $02.20-05.53$ & 4.05 & 0.2109 & 17.69 & 19.86 & 79.39 & 32.47 \\
\hline 9 & Number of pods/ plant & $03.80-13.43$ & 8.19 & 0.503 & 24.56 & 26.76 & 84.20 & 46.42 \\
\hline 10 & Pod dia. (mm) & $07.37-14.24$ & 10.31 & 0.2988 & 17.87 & 18.56 & 92.69 & 35.45 \\
\hline 11 & Pod length $(\mathrm{cm})$ & $06.69-15.60$ & 10.83 & 0.3647 & 17.63 & 18.57 & 90.13 & 34.48 \\
\hline 12 & Leaf length $(\mathrm{cm})$ & $05.23-12.53$ & 9.08 & 0.3563 & 19.94 & 21.07 & 89.58 & 38.88 \\
\hline 13 & Leaf width $(\mathrm{cm})$ & $04.20-09.80$ & 6.74 & 0.3002 & 15.25 & 17.09 & 79.60 & 28.03 \\
\hline 14 & Single pod weight (g) & $02.53-06.67$ & 4.85 & 0.1513 & 19.27 & 20.01 & 92.70 & 38.21 \\
\hline 15 & Plant height $(\mathrm{cm})$ & $25.23-119.6$ & 43.07 & 2.1258 & 42.45 & 43.30 & 96.34 & 85.73 \\
\hline 16 & Number of seeds/ pod & $02.17-06.10$ & 4.53 & 0.3703 & 16.08 & 21.43 & 56.27 & 24.85 \\
\hline 17 & Seed length $(\mathrm{mm})$ & $08.24-16.74$ & 13.82 & 0.1032 & 13.13 & 13.20 & 99.04 & 26.92 \\
\hline 18 & Seed width (mm) & $04.81-08.55$ & 6.79 & 0.069 & 11.78 & 11.91 & 97.82 & 24.01 \\
\hline 19 & 100 seed weight $(\mathrm{g})$ & $12.47-46.47$ & 33.04 & 0.7144 & 22.65 & 22.96 & 97.34 & 46.04 \\
\hline 20 & Seed yield/plant (g) & $03.44-27.84$ & 12.29 & 1.0394 & 39.72 & 42.34 & 88.03 & 76.77 \\
\hline 21 & Pod yield/ plant (g) & $13.48-62.59$ & 38.08 & 3.6139 & 27.59 & 32.12 & 73.80 & 48.83 \\
\hline 22 & Pod yield/ ha (q) & $26.95-125.19$ & 76.15 & 7.2277 & 27.59 & 32.12 & 73.80 & 48.83 \\
\hline
\end{tabular}

GM : Grand Mean GCV : Genotypic Co-efficient of variability, PCV : Phenotypic Co-efficient of variability

weight, number of pods per cluster, leaf length, single pod weight, pod diameter, pod length, number of pod clusters per plant, leaf width, seed length, number of seeds per pod and seed width indicated that most likely the heritability is due to additive gene effects interns these traits were less influenced by environment and selection may be effective for further improvement. Similar results of high heritability and high genetic advance as per cent of mean for french bean were also reported earlier for plant height (Kamaluddin and Ahmed, 2011; Singh and Singh, 2013; Prakash and Ram, 2014; Bhaganna et al., 2015; Prakash et al., 2015 and Mukesh and Geeta, 2016), for seed yield per plant (Kamaluddin and Ahmed, 2011; Singh and Singh, 2013), for pod yield per plant (Rai et al.,2010; Singh and Singh, 2013; Prakash and Ram, 2014; Jyoti et al.,2015; Prakash et al., 2015; and Mukesh and Geeta, 2016), for pod yield per hectare (Singh and Singh, 2013; Prakash and Ram, 2014; Singh et al.,2014 and Prakash et al., 2015), for number of pods per plant (Rai et al.,2010; Prakash and Ram, 2014; Singh et al.,2014; Bhaganna et al., 2015; Jyoti et al.,2015 and Prakash et al., 2015), for 100 seed weight (Rai et al.,2010; Kamaluddin and Ahmed, 2011; Singh and Singh, 2013; Prakash and Ram, 2014; Singh et al.,2014; Prakash et al., 2015 and Mukesh and Geeta, 2016), for number of pods per cluster (Mukesh and Geeta, 2016), for leaf length (Prakash and Ram, 2014 and Prakash et al., 2015), for single pod weight (Singh and Singh, 2013; Singh et al.,2014 and Jyoti et al.,2015), for pod length (Rai et al.,2010; Kamaluddin and Ahmed, 2011; Singh and Singh, 2013; Prakash and Ram, 2014; Singh et al.,2014; Bhaganna et al., 2015; Prakash et al., 2015 and Mukesh and Geeta, 2016) for number of pod clusters per plant (Mukesh and Geeta, 2016), for leaf width (Prakash and Ram, 2014 and Prakash et al., 2015), for seed length (Rai et al.,2010), for number of seeds per pod (Rai et al.,2010; Kamaluddin and Ahmed, 2011; Singh et al.,2014 and Bhaganna et al., 2015) and for seed width (Rai et al.,2010) in french bean.

High heritability coupled with moderate genetic advance (Table 3 ) was found in french bean for days to 50 per cent flowering (Kamaluddin and Ahmed, 2011, Prakash and Ram, 2014, Singh et al., 2014, Prakash et al., 2015), days to first flowering (Prakash and Ram, 2014, Prakash et al., 2015), days to 50 per cent pod setting, days to 50 per cent maturity and days to $1^{\text {st }}$ picking revealed additive gene action, hence selection for such traits may be rewarding but there is slight influence of environment on these characters for further improvement. High heritability coupled with low genetic advance was found in days to $2^{\text {nd }}$ picking indicating the presence of non-additive gene action, therefore selection for such traits may not be rewarding and it suggests the creation of new variability for further 
improvement of this trait through other means.

\section{Conclusion}

The present study on french bean revealed that highest genotypic as well as phenotypic coefficient of variations were exhibited by plant height, followed by seed yield per plant, pod yield per plant, pod yield per hectare and number of pods per cluster indicating that the accessions posses a wide range of variation for these traits. High heritability coupled with high or moderate high genetic advance was recorded in plant height, seed yield per plant, 100 seed weight, number of pods per plant, pod dia, pod length, leaf length, single pod weight and seed yield per plant indicated that most likely the heritability is due to additive gene effects and selection may be effective for these traits.

\section{REFERENCES}

Allard, R.W. (1960). Principles of plant breeding. John Willey and Sons, New York, pp 485.

Anonymous (2015). Indian Horticulture Database-2015. National Horticulture Board, Ministry of Agriculture, Government of India.

Bhaganna, H., Salimath, P. M., Nagarajappa A., Asha, I. S. and Gangaprasad, S. (2015). Study on genetic variability, correlation and path analysis with green pod yield and yield attributing traits in french bean (Phaseolus vulgaris L.). The ecoscan. 7 (special issue): 41-46.

Burton, G.W. and Devane, E. W. (1953). Estimating heritability in fall fescue (Festuca arundinacea) form replicated clonal material. Agron. J. 4: 78-81.

Johnson, H.W., Robinson, H.F. and Comstock, R.E. (1955). Estimates of genetic and environmental variability in soybean. Agron. J. 47: 314-318.

Jyoti, D., Sharma, A., Singh, Y., Katoch, V. and Sharma, K.C. (2015). Genetic variability and character association studies in french bean (Phaseolus vulgaris L.) under North-Western Himalayas. Legume Research, 38 (2): 149-156.

Kamaluddin and Ahmed, S. (2011). Variability, correlation and path analysis for seed yield and yield related traits in common beans. Indian J. Hort. 68.1: 56-60.
Kaplan, L. (1965). Archaeology and domestication in American Phaseolus beans. Econ. Bot., 19: 358-368.

Mohapatra, M.R., Acharya, P. and Sengupta, S. (2007). Variability and association analysis in okra. Indian Agriculturist, 51(1/2): 17-26.

Mukesh, T. and Geeta, G. (2016). Studies on genetic variability in different genotypes of french bean (Phaseolus vulgaris L.). Int. J. Life. Sci. Scienti. Res., 2 (3): 219221.

Pandey,V., Singh, V.K. and Upadhyay, D.K. (2013). Determination of green pod yield components in french bean (Phaseolus vulgaris L.) through correlation and path coefficient analyses. Vegetos, 26 (2): 438-443.

Panse, V.G. and Shukhatme, P.V. (1967). Statistical Methods for Agricultural Workers. 2nd Edn. ICAR Publications Krishi Anusandhan Bhavan, Pusa, New Delhi-11001.

Prakash, J. and Ram, R.B. (2014). Genetic variability, correlation and path analysis for seed yield and yield related traits in French bean (Phaseolus vulgaris L.) under Lucknow conditions. Int. J. Innovative Sci., Eng. \& Tech. 6 (1): 41-50.

Prakash, J., Ram, R.B. and Meena, M.L. (2015). Genetic variation and characters interrelationship studies for quantitative and qualitative traits in french bean (Phaseolus vulgaris L.) under Lucknow conditions. Legume Research. 38 (4): 425-433.

Rai, N. Singh, P.K., Verma, A., Yadav, P.K. and Choubey T. (2010). Hierarchical analysis for genetic variability in pole type french bean. Indian J. Hort. 67(Special Issue): $150-153$.

Ram, H.H. (2014). Vegetable breeding principles and practices. Kalyani Publishers, New Delhi. pp 439.

Singh, A. and Singh, D.K. (2013). Genetic variability and character association analysis in french bean (Phaseolus vulgaris L.). J. Food Legumes. 26 (3 \& 4): 130-133.

Singh, B.K., Deka, B.C. and Ramakrishna, Y. (2014). Genetic variability, heritability and interrelationships in poletype french bean (Phaseolus vulgaris L.). Proc. Natl. Acad. Sci., India, Sect. B Biol. Sci. 84 (3): 587-592.

Swarup, V. (2012). Vegetable Science and Technology in India. Kalyani Publishers, New Delhi. pp 480.

Vavilov, N. I. (1950). The origin, variation, immunity and breeding of cultivated plants. Chron. Bot., 13: 1-364. 